Wealth Sharing for Success in Vietnam: Fishing for the Net Gain

\author{
Anne Cullen \\ American University in the Emirates \\ Dubai International Academic City, \\ P.O. Box: 503000, Dubai, UAE \\ anne.cullen@aue.ae
}

Dennis C. McCornac (Corresponding Author)

Loyola University Maryland

4501 North Charles Street

Baltimore, MD 21210 USA

dcmccornac@loyola.edu 


\title{
Wealth Sharing for Success in Vietnam: Fishing for the Net Gain
}

\begin{abstract}
This paper posits that orthodox analysis of government-business and business-business organization in Vietnam involves subtle constituency and 'beneath-the-surface' relationships, largely ignored in reviews of the post - đổi mới economy, but are nevertheless worthy of inspection. Following a review of the theoretical terrain regarding Vietnamese political-business-economy, we provide an alternative view showing how the business sector has developed net(work)s of cooperative mechanisms to work with the Vietnamese government and its bureaucrats. While a delicate interplay of politics can be identified in the net(work) relationships, such constituency politics do not seek to challenge the existing authority of the state or the ruling elite. Rather, the small-scale constituency politics are constructed to operate within the dominant polity and work with corporatist strategies to secure personal and group gain. The strategies used are unique in that they exhibit sympathy with socialism, yet succeed in exploiting the proentrepreneur characteristics of đổi mới.
\end{abstract}

Vietnam, Business Relationships, Political Economy.

\section{Introduction}

Vietnam is not an easy place to attempt to understand national politics and business relationships. Following reunification of the North and South in 1975, the nation embarked on a failed socialistic experiment which eventually placed it among the top ten least developed countries. This dire situation eventually forced the communist authorities to change course, and in 1986 the era of đổ móti, loosely translated as economic renovation, began. With the aim of keeping the nation primarily communist, therefore satisfying the countries' moral belief and convictions, đổi mó $i$ was also designed to integrate the nation's economy into the global market.

Hiebert (1996: 5-10) notes that đổi mói was a phase of reform aimed at renewing a flailing economy and even though the socialist government adopted essentially capitalist modes of production, political reform was never a part of the agenda. While freer access to land rights, capital and a choice of partners in commercial transactions are all examples of individual liberties that came as a result of đổi móri, these liberties were all introduced as part of a scheme that had almost exclusively economic ends in mind. Typically, as Karnai (2000: 29) points out the deceptive adage, free markets create free people -- as free markets are so often associated with freer societies and political environments. Vietnam, however, does not fit this mold.

This paper investigates why Vietnam sits apart from the adage focusing on the characteristics of Vietnamese đổi mói that has created a unique form of businessgovernment relations. 


\section{The Analytical Terrain}

The impact and growth of the free-market has dominated much of the post-đổ mó $i$ economic analysis of Vietnam. The analysis tends to be divided across two broad categories of study. The dominant research focuses on (inter)national economics that fosters 'investment and wealth creation'. Unsurprisingly, authors in this area concentrate on the positive effects of freer markets and examine economic development in Vietnam based on the enabling or inhibiting actions of the state (Vietnam Development Report 2012). The second area of study can best be described as 'welfare wealth creation', or how the post-đôi mó i freer markets have witnessed increases in people's living conditions, albeit with the government playing a dominant role in most achievements (Cling et al. 2013).

A common thread running through most of the analyses is that the government is involved in many of the actions post-đổi mó i and often is the agent of change. Seen in these terms, analysts deal with economic policy as an interactive process and the result of state imposition (See Sabatier 1991). In short: all analyses confirm the dominance of the state and the Vietnamese Communist Party as the ruling power.

Moore and Schmitz (2008) offer an ideal example of how government can use its blunt instruments in the investment and wealth creation category. Their analysis focuses on the instrumentality of government and suggests that,

"hand-in-hand arrangements ${ }^{1}$ between politicians and investors ... may offer a more realistic way forward in poor countries with weak public institutions. However ... such arrangements can be, and indeed have been, abused. The challenge therefore is to specify the circumstances in which hand-in-hand arrangements have the desired effect" (p.3).

In general terms they propose that any policy mission in regard to investment "is to curtail the influence of political power through formal rules, laws and institutions. If such a mission fails, politicians are expected at least to maltreat the private economy, and possibly to loot it, and thus undercut economic growth." Thus, Moore and Schmitz deny any subtle underplay of any historical or societal influences in shaping governmentbusiness relations - analysis is restricted to the reactions of government and business in accordance with the trends in investment. This open-market as cure-all approach was pithily summarized in The Economist (April 24, 2008), but again fails to allow any subtly constituency interactions:

"The Vietnam government began in 1986 with a liberalisation programme called doi moi (renewal), though real reform began in fits and starts over the following 20 years. Collectivisation was scrapped, farmers were given their own land to till and agricultural prices were freed. In 2000, private business - until then strictly curbed - was legalised and a stock market created. Trade barriers were lowered, exports and imports soared, and Vietnam is now among the world's most open economies. There can probably be no

\footnotetext{
${ }^{1}$ Not to be confused with crony capitalism
} 
going back: any attempt to reapply the dead hand of government will ensure that Vietnam's dream of riches by 2020 remains just a dream."

Where Moore and Schmitz evolve from the blunt approach of The Economist summary is when they accept that there may be a different form of analysis that "starts from the understanding that the relationship between politics and business is always actually or potentially one of interdependence" (p. 10, emphasis in the original).

Edmund Malesky (2008) moves the investment-oriented category closer to a more nuanced multi-factor understanding as he considers foreign direct investment (FDI) as the focal point for government-business relations based on a study of economic activity in the provinces in Vietnam between the years 1990-2000. The analysis contributes important knowledge regarding provincial autonomy vis-à-vis central governance, based on the clarity of numerical analysis. The work does not pretend to consider the philosophical or the ideological legacy of history. Yet Malesky astutely notes, "Provincial officials ... have three sets of incentives: prestige and power, pecuniary benefits for themselves and related family businesses, and community interests in providing employment and better living conditions for citizens in their provinces" (p.101). Malesky's observation hints at drivers beneath the surface not accountable in numerical data that lead the analysis of Vietnam's economic reforms.

In no small part, the use of investment to analyze the government and business relations in Vietnam can be attributed to the rising star effect of a post-đổi mó $i$ sustained high GDP growth rate. Any critique of that preponderant analytical framework remains in the shadows of the glittering economic results being achieved. But as the Vietnamese economy slowed in the wake of the global financial crisis (GFC) and the glittering success of the Vietnam economic project waned, analysts have started to hint at a relationship between investment and the ideological driven bureaucrats of the Vietnamese Communist Party.

In March of 2012, a headline from The Economist (March 31, 2012) proclaimed "Hero to Zero: The Communist Party sticks to its principles and the economy stalls" marking a shift in the analysis from a focus on investment and government relations to investment and ideology influenced government relations: an inclusionary analysis that does allow for subtle below the surface activities. The article went further in making a connection between an imposed ideology and government business relations when it stated:

\footnotetext{
"Amid the bustling trade and raucous traffic of the Vietnamese capital, innumerable banners exhort citizens to "Celebrate the Spring, Celebrate the Party." These days, Hanoians do not have much to celebrate. Not long ago, Vietnam was one of the developing world's pin-ups. Now it is lagging badly. . . . What is missing, now as in the past, is any detailed plan about how to implement reforms such as restructuring the clunky state-owned sector, streamlining public investment and improving transparency."
} 
The conclusion for readers is clear - the blunt economic instruments of a post-communist state are inhibiting sustained economic development. The communist government is pitted against the development trend and held to be the laggard in the post-đổ mó $i$ investment-led economic experiment of Vietnam. Such conclusions certainly offer bigpicture analysis, but do not advance a nuanced understanding of the role of individuals, citizens, and traditional societal structures in the modern Vietnamese economy.

Khanh Vu Duc (2013) enters the analytical terrain by subjugating the investment-led growth into the second category of wealth creation by acknowledging the core idea of post-đổi mói investment, but links the outcomes to wealth creation for individuals: "Only through market-oriented reforms known as đổi mó $i$ implemented in the mid-1980s was Vietnam spared total economic collapse. Those reforms allowed foreign investment to enter the country and as a result raised living standards." How this occurred is omitted. Political reform is assumed. Relationship net(work)s are not yet suspected. The blunt form of analysis certainly explains what happened, just not how society and the prevailing ideology, for example, assisted to facilitate to development and wealth growth.

The need for political reform permeates the post-GFC analysis, but it remains unsure which model of polity is required. Democracy is often put forth as the hope for wealth creation that is inclusive of citizens and their personal fiscal growth. With tantalizing perceptiveness, Khanh (2013) moves close to including the role of the societal historical practices, pulling back at the last moment to remain in the safer environs of 'democracyas-a-generic-cure-all' when he notes: "While a functioning democracy aims to reflect the customs, cultures and aspirations of its citizens, there is no existing model of democracy that can readily address Vietnam's contemporary needs and wants." While agreeing that a one-size-fits-all model of democracy does not exist, Khanh stops short of exploring the model that does fit for Vietnam.

Benedict J. Tria Kerkvliet's (2012) analysis of the Vietnamese political system discourages any generic democratic understanding when he declares, "Despite being a one-party state, Vietnam's political system has often been responsive to peasants, workers and others pushing for better economic, social and political conditions." Kerkvliet places the welfare of the Vietnam people at the centre of his analysis thereby incorporating the probability that there are historical-cultural structures, outside of orthodox business-government relations, at play in the Vietnamese polity. Evidence of a greater polity becomes evident when Kerkvliet tells us that historically,

"Major policy shifts in the last 25 years - especially replacing a centrally planned economy with a market economy and abandoning collective farming in favour of individual household farming - have been consequences, to a considerable measure, of bottom-up pressure for change, to which the country's Communist Party leadership has acquiesced.

Kerkvliet's message is clear: pluralism has historically existed in the post-đổ mó $i$ Vietnamese political system. Moreover, that Vietnamese polity is more complex than a simplistic reading of government/investment/business relations. 
A earlier DFID (2010) report first hints at this complex analysis arguing that donor analysis of Vietnam should "acknowledge the political dynamics of growth, including that some forms of informal relationships between business and state in developing countries can succeed in generating and sustaining high levels of growth" (p.9). DIFD are unapologetically concerned with the welfare of the Vietnamese people, and lead the analytical terrain by accepting a subtle interplay of relationships existing between the government policy makers, and investment (p. 87).

Common across all analysis in the post GFC period is a discussion on role of bribery in government-business relations and its inhibiting effects on growth: both investment and welfare. At times, discussions on bribery tend to assume a Western intensity of the action. As such the conversations are not educative as they neglect the cultural subtlety required to comprehend the Vietnamese notions of bribery versus wealth sharing. Anthropologists, however, do allow for a finer understanding of this type of wealth sharing. Chan (2006) for example, argues that attention be paid to the reported experiences of people. In assessing the macro (politico-political context) experience of Việt Kiều ${ }^{2}$ in northern Vietnam undertaking micro (personal experiences) business activities, one informant summed up Vietnamese business interactions with "... the Vietnamese like to take advantage of others" (Chan 2006, p. 226). Terminology such as 'corruption' is not used. Rather a broader idea of wealth sharing is imagined. Sharing a common bond with the politico-economic literature informants, the sociological informants validate society-wide problematic relationships with Vietnamese bureaucrats (p.227) only hinting at corrupt practices.

Whenever the issue of bribery is raised, the overall assumption is that society is seen as having little ability to check the state's dominance because of all stakeholders are adhering to prevailing cultural, political and institutional constraints; including a compulsion for bureaucrats to facilitate đổ mót that fiscally benefits the business operator rather than the government official.

What is neglected is any discussion is how Vietnamese bribery is different to our universal notion of bribery. The literature does not ask if there are unique characteristics to the bribery structures, and, if there were, what they might mean for the framework of investment-welfare-and economic growth in Vietnam today. To ask these questions requires intimate knowledge of internal and individual Vietnamese relationship structures (individual to business and business to government) and social norms that have grown out of the Vietnamese historical and societal milieu and are well honed to garner wealth and prestige to oneself and used to elevate social and economic standing. Most importantly, understanding may require a reconceptualization of what 'bribery' seeks to achieve: a redistribution of wealth through personal and/or formal net(work)s.

\footnotetext{
${ }^{2}$ Việt Kiều literal translation remains 'Vietnamese living abroad'. More recently, the usage has evolved to mean 'once lived abroad'.
} 
Noted Vietnam researcher, Martin Gainsborough (2010) agrees. He asserts that "by studying issues to do with politics and more pertinently power" (p. 2-3) we can add to the body of knowledge about the machinations of the Vietnamese polity. Most importantly, Gainsborough's argument assumes that analysts should look to the role of particular actors and historical relationships and networks that can assist bring into being an embedded understanding of Vietnam and the practices therein. In a recent article Gainsborough (University of Bristol 2013) again proposed that "the orthodox account [of Vietnamese polity] downplays areas of continuity in both economics and politics during reform years and it doesn't account for the spontaneous 'bottom-up' initiatives that were only subsequently formalized by the elite." The continuity brings to the modern Vietnamese economy modes of operation embedded with socialist ethics and internalized triggers to ensure that wealth is redistributed through net(work)s for individual and group success. This complex interplay of society-history-economic-politico relationships, and their impact on doing business in Vietnam, is the departure point for this article. This paper adopts the responsibility to include these oft hidden social norms and behavior triggers of the Vietnamese polity in the post- đổi móri economy.

\section{The Vietnam Experience}

The idea of đổi mói remains as pertinent in Vietnam today as in the mid-1990s, and has created a curious amalgamation of social ethic and entrepreneurship that impact on domestic politics differently from other emerging Asian nations. The corporatism that exists looks and works somewhat differently to orthodox interpretations, albeit the outcome is similar. Likewise notions that all politics are centred in Hà Nội, and the outer provinces are irrelevant in policy formulation and implementation, miss a crucial element of the complex interplay of Hà Nội politics (Koh 2001). The interpretations that state categorically that all political decisions and favours are predetermined due to provincial allegiances remain closed to the input of politics to the expanding business opportunities opening to politicians, bureaucrats and ordinary Vietnamese. On this point, Jonathan London (2013a) recently noted the government strategy of bolstering "its subjective legitimacy through a precooked public consultation." Releasing political pressure via a 'public engagement' steam valve, he argues, has been a successfully tested strategy historically. However, in 2012 and 2013 the strategy "morphed into an unprecedented assault on the principle of one-party rule" and "Vietnamese of diverse backgrounds have found their political voice and have taken to the web, airwaves, and printed page in a flurry of free speech without recent historical parallel. They have derived inspiration from each other. And they have made their presence known" (London 2013a). None of these actions have sought overthrow of the ruling elite, rather they seek a greater constituency voice and a diminution of corporatist structures that preclude the average Vietnamese taking advantage of đổi mói . So while comments such as London's discharge examples of constituency politics as aberrant, most analysis compels a view of Vietnamese political relationships acknowledging a strong state with clear patrimonial links. As with London, however, most contemporary analysis also hint at some form of polity where relationships are powerful have evolved from the legacy of a socialist past, and importantly, the present. 
Consequently, it is important to now search for a model of political analysis that can meld the reality of a burgeoning 'private' sector feeding the economic success of Vietnam with the philosophical reality of 'sharing for success,' the heritage of socialist politics. The search rapidly divulges this notion as existing in the most elite political power source: the communist government proclamations. Government chants such as cho người dân, do dân, và của nguoòi dân (for the people, by the people, and of the people) reaffirms the socialist notion of 'sharing for success' while encouraging a pluralist reading of the relationship between the government and the people and their combined interest in development. This chant hints at a complex interplay between constituencies and government. Another government chant firmly embeds the idea of Vietnamese polity becoming an amalgam of socialist philosophy with contemporary and complex reality: nguời dân biết, dân bàn, thực hiện và đánh giá (the people know, discuss, implement, and evaluate) (Kerkvliet and Marr 2004: 2).

While such rhetoric does not give explicit permission for participatory engagement, it does acknowledge a politically active citizenry embraced within an animated Vietnamese polity (Plattner, 2010). As a result, any model needs to move beyond analysing only elite politics; those that occur in the halls of power in Hà Nội and are restricted to the known power relationships imbedded in the laws and policies of Vietnam and that push the political will of the elite down through all levels of Vietnamese society. This paper posits that it is possible to transcend these orthodox interpretations of Vietnam's politics and incorporate constituency politics to explain the more subtle, but certainly robust, political and interplay that occurs 'beneath the surface' of Hà Nội politics. This, in turn, provides insight to the complicated world of Vietnam's business and economic environment.

\section{Fishing Nets ${ }^{3}$}

The research issue is how political, as well as business/economic, decisions are made that are robust and enactable. To comprehend the net(work)s concept, one must first understand, then, step outside the immediate and obvious political arena. The Socialist Republic of Vietnam remains just that, a socialist state, and the polity certainly reflects this reality. The majority of serving bureaucrats are Russian trained and imbued with the ethos of Marxist-Leninist philosophy. Those who aspire to promotion and advancement are members of the politically and socially dominating Communist Party of Vietnam and the government of Vietnam continues to remain the most powerful organ of the state.

However in existing state-qua-state interpretations of politics the state is viewed passionately as both the inhibitor of sound policy and as the prohibitor of constituency participation in policy or democratisation processes as it unremittingly acts in its own self

\footnotetext{
${ }^{3}$ This term and original concept is the result of participatory observation by the authors while they were residents of Hà Nộ In some instances, the details regarding the fishing net system, comes from formal interviews. Other aspects of the model were forthcoming in informal discussions with local business and government representatives.
} 
interest. As a result, the wrong assumption about state dominance and state centrality in all policy formation processes is made and examples of policy formation that exhibit constituency politics characteristics are missed (see Kerkvliet, 2005). Analysts that maintain a state-centred focus are correct, however, in assuming a corporatist structure in Vietnamese politics. The Vietnamese government is less concerned with interest representation than control and power over its constituents. The philosophy, language and ethic and institutions of the Vietnamese government are continually structured to promote common national good, and while indigenous Non Government Organizations are not encouraged, the mass Communist Party based organisations certainly act as functional units for state control.

The Farmers' Association, for example, has behaved within the corporatist structures, and produced change up-ward: officers claim to have influenced the 1993 Land Law (especially on the transfer of rights). Such changes, however, do not impact on the nature of the Goliath communist state. Likewise, some mass organizations have also diversified to become economic service providers for their members (Shanks 2004). And the Women's Union organizes HIV prevention, micro-credit schemes and support for private enterprise which tends to further increase the independent political space within which the mass organizations can operate - to a degree.

That said, there is also evidence that the "Vietnamese political system is based on patronclient ties: the relationship between two or more individuals of unequal rank or stature. In return for support and protection, the client owes his patron unquestioned loyalty and support, thereby establishing and legitimizing the corporatist structure for constituencygovernment relations" (Abuza 2001a).

Moreover, strict state-qua-state analysts ignore the interplay of constituency politics which have emerged as a legacy of the socialist philosophical traditions, and the state ideology imbedded in all state policy and documents, namely, "Độc lạp - Tụ do - Hạnh phúc," (Independence-Freedom-Happiness). This slogan was specifically stated in the preamble to the original constitution in 1946 as well as the subsequent amended constitutions (Vietnam Constitution 1992) and the concept has been firmly indoctrinated in the population. As a result, the methodology of constituency politics follows the ideology: people have the right of independence in their political and economic endeavours to ensure their freedom from the personal and national scourges of the past and ensure their future happiness. This is a belief not contradictory to the capitalist notions attached to Đổi Mới. But in pursuing Độc lập - Tụ do - Hạnh phúc the people are equally committed, because of socialist ideologies, to ensure that all benefit (somewhat) uniformly both in fiscal and personal advancement. In saying this, we do not deny the existence of economic and political strata in Vietnamese society. Any equality through sharing remains largely within the socio-economic strata of the individual actor(s), which have been exacerbated and consolidated since đổi mó i. For example, the notion of 'sharing' does not naturally extend to redistribution from the elite to the poorest of the poor. Sharing is culturally encoded and follows very strict rules that are rarely interfered with, as will be seen below. 
The potential for indigenous networks to operate unhindered by imperialism or conflict has only existed since the early 1970s. More than a millennium of domination by China and subsequent colonization by the France in the late 1800's and lasting until France's defeat at Điện Biên Phủ' in 1954 have meant the indigenous power structures, overshadowed by foreign influences, has precluded the emergence of structures that facilitate one powerful person dominating sectors. Despite, or possibly because of, the protracted imperialism experienced in Vietnam, socialism and its incumbent notions of equity resonated in the will of the people and a nascent leadership that wished an independent Vietnam for the Vietnamese people. Only after the withdrawal of foreign forces and the reunification of the country in April 1975 were indigenous power relationships able to emerge and shape a now independent and socialist Vietnam.

The system of redistribution and power relationships that did emerge can most appropriately be thought of in terms of fishing nets. Fishing nets when in operation capture a variety of fish; and never do two fishing nets catch exactly the same number or type of fish. Rather the fish are varied in species and value. Likewise the political and business nets of Vietnam hold an often eclectic number of individuals. The importance and worth of identities within the net is fluid depending on the issue at hand. To best understand the Vietnamese nets we need to look at the structure, nature and aims of the net(work)s.

All the nets have static and non static elements. The static elements are evident largely for those people fortunate enough to be born into families of power and prestige: that is, ranking party members. For them, there are established net(work)s that are cultivated and to which they have immediate access in their political and business dealings. For Vietnamese officials, for example, the key question at a congress is whether someone you are connected to personally or through your workplace moves up or out as a result of the circulation of positions, and what this means for you, your institution, or your family in terms of the provision or loss of protection and access to patronage. In Vietnam, holding public office gives you access to patronage, which can range from access to the state budget and the ability to make decisions about how to spend public money, to the authority to issue licenses or other forms of permissions, to carry out inspections, or to levy fines. The result is that people come to you hoping for services or favors or generally to try influence you. Equally, if you hold high office, people do not want to cross you for fear of what you might do to them. Whether such fears are really justified is debatable, but certain positions carry with them a reputation that gives the office holders, and people close to them, a degree of protection in what can be a nasty and brutish political environment. Against this backdrop, it is no wonder that public office in Vietnam comes with a price tag, since it is well understood that buying a seat is an investment that can be recouped.

There are some characteristics of the accumulation, however, that remain static. An individual may, for example, inherit at least entry to a particular net(work) through birth. One of the first questions between Vietnamese is framed to ascertain the family origins of 
a new contact. This is more than cultural interplay: the question is designed to determine the potential importance of an individual due to family and provincial connections. Vietnam is, by many international comparisons, a newly emerging small nation. With a population level of slightly less than 90 million, it has most importantly maintained a small-village structure to relationships and communication. Consequently news/information/gossip (thông tin tin đồn) travels like greased-lightening between interested, and, often, disinterested parties.

The question of family/(culture) village positioning and relations is also posed to foreigners seeking to do business in Vietnam; however the reason for asking alters. The questioner is not seeking to know familial relations, but rather the question is encoded and sets a multi-faceted test for the respondent. At the surface level, the questioner is indeed ascertaining the origins of the respondent and listening for clues about the respondent, and their potential value in terms of social/net(work)s, from the answer. But more importantly the questioner is looking for deep understanding of Vietnamese culture in the response and listening for linkages that may be of use to the expansion of his own net. So when, typically, a Westerner replies simply with nationality and curriculum vitae of employment and corporate associations, the questioner does not hear information of direct importance to him. Rather a Vietnamese is listening for a response that resonates with Vietnamese social and philosophical practices: and for a foreigner that is, surface information underwritten with reassurances that the Westerner's origins are not of utmost importance. More pertinent are relationships the Westerner wishes to establish with the Vietnamese questioner so as to achieve the end goal of mutual gain, and what existing net(work)s s/he may have to attain that goal, while using Vietnamese social etiquette to transmit all that information appropriately. Communicating all this demands a deep understanding of the verbal and non-verbal dance that aspirant net(work)s inductees must perform. The communication is delicate and fraught with potential missteps.

This form of missed-cultural communication is not unique to Vietnam and but is known in to exist in post-communist states as explored by Vlachoutsicos and Lawrence (2007) when they note, "Indeed, very often local managers themselves do not realize how they carry attitudes which have their roots in the Soviet system from which, at a conscious level, these young people vehemently distance themselves, until something happens that triggers these deeper layers of feeling." Such an observation serves the Vietnam example well: foreigners, especially Westerners, can trigger Vietnamese deeply held socialist ideological beliefs with a wrong statement. The Westerner walks a fine cultural path here: any 'mutual gain' goal must not be explicitly stated - to do so would be insulting. Blundering will result in failure to thrive in the post đổi mó $i$ Vietnam.

Much time is spent in Hà Nội (by Vietnamese and Westerners alike) establishing the intersections of nets and people. Having such information at one's fingertips is not only collateral in Vietnam but also a way to broadcast to others that you have intersecting nets of importance. Having such knowledge carries with it implicit meanings. First the person bearing the 'news' is of at least equal standing to the subject of the news. Second, she or he may be trusted to understand the implicit rules of your networks; the unwritten 
agreements and pecuniary arrangements, mainly since s/he is already acquainted or doing business with another member. These pecuniary arrangements vary slightly from net-tonet, however all can be generalised on one point: members all understand and concur with the sharing arrangement of any 'commission' that results from business transactions. 'Commission' should not be confused with the Western idea of 'Darwinian corruption' and its inherent costs to business in the competitive landscape. None of the four dimensions of competitiveness - external business relations, interaction with regulators, public reputation, and the morale of its employees - explored by Serafeim (Nobel 2013) are found to be negatively affected by the capture nets of Vietnam business relations.

Membership to the net(work) does not automatically entitle one to a share of the commission; rather the distribution is strictly restricted to those immediately involved in the deal. The trick is to be situated in such a way so as part of the deal will be channelled through your own business or political resources. This can be achieved through merit or friendship. Merit means that one's business interests, political connections and resources are of direct importance to a business deal. Friendship comes into play when one party wishes to show largess and share with a third (or more) party at the cost of a larger share for him/herself. For example if actor A engages with actor B on a specific deal, actor A may request that actor $\mathrm{B}$ pass all information regarding the deal through actor $\mathrm{C}$, who has no direct input into the deal, yet his/her acting as a conduit facilitates actor A sharing their commission with actor $\mathrm{C}$ as "they are friends and friends must take care of each other, if only a little, just a little bit." 4 This strategy reaffirms both the notion of friendship and the enduring strength of the net through mutual contacts. ${ }^{5}$

Members of nets are seen as friends who are of importance to an individual. Some will be genuine and enduring friends. Others will be nominal friends. One fact remains constant: while friends are slightly different for each net, each associate for the redistribution of monies and generating business opportunities for oneself primarily and 'friends' secondarily.

Likewise, knowing the broader kinship relations of the elite political and business elite is also considered vital if one wishes to be encapsulated into a powerful net(work). This knowledge assists the aspirant to identify pertinent individuals and target them directly, or begin to inculcate other relations that will ultimately lead to being caught up in the sought after net. For others born to positions of power or privilege knowing the relationships merely affirms the nets to which they have access.

\footnotetext{
${ }^{4}$ Confidential interview with a leading Vietnamese business identity.

${ }^{5}$ Westerners do not at first glance seem as adept at this strategy. To be sure they are not as intuitive about Vietnamese nets, but those wanting to cultivate business dealings with Vietnamese individuals soon learn the fundamentals. Interestingly, the internal 'long noses' nets are generally known with astounding clarity seeming to indicate commonalities across the cultures that are either internal or learned as part of the Hà Nội business-politics dialect. The Westerners use the same vernacular to describe their knowledge of their and others' connections often using the expression, for example, Hà Nội /Vietnam is a small place'. This is certainly true for foreigners in Vietnam, and there is usually only one degree of separation between any two foreigners if they are not yet acquainted.
} 
The net(work)s rely on a constant rise through the political and business hierarchy in their internal and external relationships. Without an internalised ascending power structure the net(work)s would be ineffective as the members would simply be a cohort of similar (business and political) level pals who lack the ability to advance business and political ambitions. The very purpose of the net(work) power structure is to achieve personal financial and political security that is not achievable by cultivating and maintaining friendships with others of the same ilk. Consequently the internal politics of the net(work) becomes a drama where the members are constantly on the lookout for members who have/are actively cultivating 'friendships' with grander elite. But while the net(work)ing individual in the net(work) will be willing to talk about his 'new friend', he will also be exceptionally cautious regarding introductions for net-members to the honoured person. Gaining close contact with a member of grander elite is somewhat like a coup de grace and is an excuse, in some circumstances, for much boasting with other trusted net(work) members. After some time the net(work) member may act as an intermediary and introduce a peer member to the individual of the grander elite. But only if $\mathrm{s} /$ he feels confident that the peer will be appropriate, respectful and more to the point, an individual the grander elite wishes to make acquaintance. Even differing elite ranks will likely have socialised in large gatherings, and as such will be at least be on nodding terms with each other, if not more closely acquainted. But to get to the point of a meaningful invitation to meet with grander elite may take years. Again it is important to reinforce that these motivations are rarely spoken out loud, and the subtle political interplay involved in the decision making is a silent outcome of the culture of business and politics in Vietnam. Net(work) members must cultivate patience as well as business. The goal is to have personal 'friendships' up through multiple levels of the political and business communities.

The beauty of the net(work) system, however, is that it is not always mandatory for each individual to have an extensive net(work) that penetrates to the upper echelons of the political and business hierarchy. Instead one can call on the net(work)s of one's peers by incorporating the peer into the business proposition. The trade off becomes a sharing of profit/commission in return for an introduction to the (usually) political elite who can facilitate/expedite needed licences/permission/instructions so the project may proceed post-haste. Sharing is not a problem here. While one seeks to limit the amount of sharing that must be incorporated by strategically choosing appropriate business partners, one also understands that there must be a component of sharing within one's peers to maintain respect and membership within the net(work). One shares for the wealth of the whole rather than the individual. But we should not take this socialist ideology as meaning that each member is seeking to elevate the status of the net(work): that privilege remains the exclusive opportunity of the individual.

So as a result the net(work)s may be conceptualised as concentric but diminishing loci radiating out from a project, either business or political. Observing the localized net(work)s should not, nonetheless, be viewed as insights into fundamental shifts in the status quo in Vietnam politics. This would be a wrongful interpretation. Wealth development and sharing continues to rise in Vietnam, and as political science folk-lore 
has it, populations are content to abide with an authoritarian regime so long as their personal wealth continues to rise year-on-year. But to gain a full understanding of the process by which outcomes emerge, it is also necessary to take into account the structure of the domestic and international economy and the relationship between politics and the economy, also operating domestically and internationally. In all of this, special attention needs to be paid to the informal realm so we are not duped into taking formal rules for granted (Gainsborough 2007). And despite the changing economic environment in Vietnam over the past decade, the observations of state-qua-state analysts such as Abuza (2001b) still ring true and Vietnam polity does not yet have the critical mass of agents of change: the "organized and autonomous groups with their own authority system and ability to organize, articulate views, and represent the interests of their constituency" (Abuza 2001b: 9).

The recent McDonalds Corporation entrance to Vietnam provides some pointed evidence of the not-so-oblique machinations of the government-business nets. On July 152013 McDonald's announced that Henry Nguyen, a Vietnamese businessman and the founder of Good Day Hospitality, would receive a developmental licensee for Vietnam to "build their brand in Vietnam" (Vietnam News 2013). Official statements reiterated the corporate message that Nguyen's business credentials merited his selection to represent the corporate brand. Social networking responses, however, point to a very different selection process at play.

Vietmeme.net (2013), a social blog purporting to deliver even-handed analysis of events in Vietnam, offers a representation of the societal response and pointed alludes to beneath-the-surface activity with:

Yet perhaps more important is the fact that, in a country like Vietnam, where the system is seen by many as being overwhelmingly aligned against the ordinary working class, and where it's conventional wisdom that the only way to get ahead in Vietnam is to be there already, news of the Dung-Nguyen-McDonald's alliance does little to assure people that opportunity in Vietnam exists for anyone except the most highly placed elites - those who in fact need it the most.

Further investigation into the true circumstances confirmed that Vietmeme.net was correct in its statements. The official announcements failed to mention Henry Nguyen's Việt Kiều status and a heritage ${ }^{6}$ which should legally preclude his status as the son-in-law of Prime Minister Nguyen Tan. Attitudes in regards to Việt Kiều may be softening in a globalizing and post-GFC Vietnam, but as Vietmeme.net (2013) ponders "old traditions die hard here [Vietnam]" and Nguyen gained access to the most elite of wealth sharing nets on two known and respected criteria: marriage and business acumen. Accusations of outright corruption are avoided by Vietnamese observers. In part this is the result of a deep understanding of the net(works) that are not culturally considered 'corruption', in a Western sense, but the irregularities they create are well noted. This is borne out by the acerbic statement, "Perhaps it is only coincidence that out of 90 million possible

\footnotetext{
${ }^{6} \mathrm{He}$ is the son of Nguyen Bang, who was on official in the defeated Republic of South Vietnam. As such Henry is technically forbidden to marry any member of the communist party.
} 
candidates in the country, the Prime Minister's son-in-law happens to be the only one with the best qualifications for this rare opportunity. If so, that's some coincidence." (Vietneme.net 2013) As a result, the void of accusations is the result of a knowing society, and, the lack of the critical mass of agents to effect change at such an elite level.

\section{Conclusion}

This article supports the analysis that the dominant political culture in Vietnam is, and will continue to be, dominated by the Communist Party of Vietnam machine. But with that admission we do not concede that the Party is all-powerful. Indeed recent analysis would seem to support a slight 'bending' in the governmental controls (London 2013b). However, we have shed light on the 'below-the-surface' political activity that exists and persists throughout the business-business and government-business relationships in Vietnam and present evidence of the pluralist behaviours in these relationships that have hitherto been bypassed in orthodox state-qua-state analysis of Vietnamese polity. Our intent is to haul the government-business net(work)s into the analytical light for further inspection. Certainly the net(work)s represent the existence of a particular type of constituency politics at play in Vietnam. Moreover, the politics of the net(work)s remain compatible to the dominant communist philosophy of sharing wealth for success. Taken as a whole, the existence and persistence of the net(work)s encourages a conclusion that the polity of Vietnam is a more complex process than previously thought. 


\section{References}

Cling, J.P. Razafindrakoto M. and F. Roubaud (2013) "Is the World Bank compatible with the 'Socialist-oriented market economy?, Revue de la Regulation, Vol. 13 No.1, Available at: http://regulation.revues.org/10081 (accessed October 30, 2013).

Abuza, Z. (2001a), “The lessons of Le Kha Phieu: Changing rules in Vietnamese politics", paper presented at the conference Prospects for the Constituencies of Vietnam in Changing Times, Catholic University of America, Washington DC, 16 November 2001, Available at: http://www.vpa-inc.org/conference/pdf/abuza3.pdf (accessed March 25, 2013).

Abuza Z. (2001b), Renovating Politics in Contemporary Vietnam, Lynne Rienner, Boulder, CO.

Chan, Y.W. (2005), "Vietnamese or Chinese: Viet-kieu in the Vietnam-China borderlands", Journal of Overseas Chinese, Vol. 1, No. 2, pp.217-232, Available at: http://tailieu.tapchithoidai.org/Viet_Kieu_in_Borderlands_Wah_Chan_Yuk.pdf (accessed November 1, 2013.

Constitution of Vietnam, (1992), Available at http://www.na.gov.vn/htx/English/C1479/ (accessed March 28, 2013).

Department for International Development (2010), The politics of poverty: Elites, citizens, and States: Findings from ten years of DFID-funded research on Governance and Fragile States 2001-2010, Available at: https://www.gov.uk/government/uploads/system/uploads/attachment_data/file/67679/plc y-pltcs-dfid-rsch-synth-ppr.pdf (accessed November 8, 2013)

Gainsborough, M. (2007), "From patronage to "outcomes": Vietnam's Communist Party Congresses reconsidered.” Journal of Vietnamese Studies Vol. 2 No. 1, pp. 3-26.

Gainsborough, M. (2010). Vietnam: Rethinking the State. Zed Books, London, UK

Hiebert, M. (1996), Chasing the Tigers: A Portrait of the New Vietnam, Kodansha, Tokyo, Japan.

Khanh, V.D. (2013), "Visions of a democratic Vietnam", Asia Times Online, 29 August, Available at: http://www.atimes.com/atimes/Southeast_Asia/SEA-01-290813.html (accessed November 2, 2013).

Kerkvliet. B. J. T. (2012), “Reconsidering Vietnam's political system”, East Asia Forum, 26 November, Available at: http://www.eastasiaforum.org/2012/11/26/reconsideringvietnams-political-system/\#more-32252 (accessed November 4, 2013). 
Kerkvliet. B. J. T. (2005), The Power of Everyday Politics: How the Vietnamese Peasants Transformed National Policy, Cornell University Press, Ithaca, NY.

Kerkvliet, B. J. T. \& Marr, D. G. (2004), "Beyond Hanoi: Local Government in Vietnam.” Institute of Southeast Asian Studies: Singapore.

Koh, David. (2001), "The politics of a divided party and Parkinson's State in Vietnam." Contemporary Southeast Asia, Vol. 23 No. 3, pp. 533 - 551.

Kornai, J. (2000), "What the Change of System From Socialism to Capitalism Does and Does Not Mean." The Journal of Economic Perspectives, Vol. 14 No. 1, pp. 27-42.

Liddle, R. W. (1987), "The Politics of Shared Growth: Some Indonesian Cases." Comparative Politics, Vol. 19 No. 2, pp. 127-146.

London, J. (2013a), "Impatience in Viet Nam," The New Mandala, 18 March, Available at: http://asiapacific.anu.edu.au/newmandala/2013/03/18/impatience-in-viet-nam/ (accessed May 1, 2013)

London, J (2013b), “Vietnam's People are Finding Their Political Voice.” South China Morning Post, 15 May, Available http://www.scmp.com/comment/insightopinion/article/1237703/vietnams-people-are-finding-their-political-voice (accessed May 18, 2013).

MacIntyre, A. (1990), Business and Politics in Indonesia. Allen and Unwin, Sydney, Australia.

Malesky, Edmund J., (2008) "Straight ahead on red: How foreign direct investment empowers subnational leaders"). Journal of Politics, Vol. 70, No. 1, pp. 97-11.

Moore, M., and Schmitz, H. (2008), Idealism, Realism and the Investment Climate in Developing Countries, IDS Working Paper 307, June, Institute of Development Studies, Sussex University. Available at: http://www.iadb.org/intal/intalcdi/pe/2009/02458.pdf (accessed September 12, 2013).

Nobel, C. (2013), "The real cost of bribery", Harvard Business School Working Knowledge, 4 November, Available at: http://hbswk.hbs.edu/item/7325.html (accessed November 10, 2013).

Plattner, Mark F. (2010) "Populism, pluralism and liberal democracy", Journal of Democracy, Vol 21 No 1, pp. 81-92.

Sabatier, P. (1991), “Toward Better Theories of the Policy Process", PS: Political Science and Politics, Vol. 24 No. 2, pp. 147-156. 
Shanks, E., Luttrell, C., Conway, T, Vu, M.L. and Landinsky, J. (2004), Understanding Pro-poor Political Change: The Policy Process, Overseas Development Institute, London, UK.

The Economist (2008), "Vietnam: Asia's other miracle," 24 April, Available at: http://www.economist.com/node/11089442 (accessed September 12, 2013)

The Economist (2012), "Hero to zero: The Communist Party sticks to its principles and the economy stalls", 31 March, Available at: http://www.economist.com/node/21551538 (accessed September 12, 2013)

University of Bristol (2013), "Vietnamese reform influences design of government interventions", Research Society and Economy, Webpages. Available at:

http://www.bristol.ac.uk/research/impact-stories/2013/reform.html (accessed November 1, 2013).

Vietmeme.net (2103) Food fight: McDonald's long-awaited entry to Vietnam draws fire, 5 August. Available at: http://vietmeme.net/2013/08/05/food-fight-mcdonalds-longawaited-entry-to-vietnam-draws-fire-fans/ (accessed November 3, 2013).

Vietnam News, (2013), “McDonald's to debut in Viet Nam”, 17 July, Available at: http://vietnamnews.vn/economy/242178/mcdonalds-to-debut-in-viet-nam.html (accessed, July 31, 2013).

Vlachoutsicos, C.A. and Lawrence, P. R. (2007), “Don'ts" and "do's": Insights from experience in mitigating risks of Western investors in post-communist countries, Harvard Business School Working Paper. Number 07-041. Available at: http://hbswk.hbs.edu/item/5601.html (accessed October 23, 2013)

World Bank (2012) "Market Economy for A Middle-income Country, "Vietnam Development Report" Number 65980. Available at: http://web.worldbank.org/WBSITE/EXTERNAL/COUNTRIES/EASTASIAPACIFICEX T/VIETNAMEXTN/0,,contentMDK:22416790 menuPK:387571 pagePK:2865066 piP

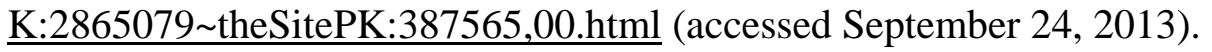

